\title{
Diffusjon av influensa i Norge under spanskesyken 1918-19
}

\author{
Svenn-Erik Mamelund \\ Hovedfagsstudent i samfunnsgeografi, Institutt for sosiologi og samfunnsgeografi, Universitetet $i$ Oslo \\ Telefon 22004484 Telefax $22864988 \quad$ E-post sem@ssb.no
}

\begin{abstract}
SAMMENDRAG
Spanskesyken var en verdensomspennende influensaepidemi som tok livet av minst 30 millioner mennesker, de fleste i løpet av noen få høstmåneder i 1918, men den strakk seg også inn i 1919. En siste svak bølge fant sted vinteren 1920. De første sporadiske tilfellene av spanskesyken i Norge oppsto i militærleire i begynnelsen av april 1918. Over tre måneder senere kom de første spredte tilfellene av det som skulle vise seg å være starten på en ny stor influensapandemi. De første av disse oppsto i Kristiania, mest sannsynlig etter smitteimport fra Skottland over Nordsjøen. Sommeren 1918 spredte spanskesyken seg raskt fra sør til nord, fra kysten til innlandet innover fjordene, og fra de største byene og industrisentra via mindre byer og andre tettsteder til landsbygda langs de viktigste ferdselsveiene. Da spanskesyken blusset opp igjen høsten 1918 spredte den seg langsommere og trolig fra nord til sør, fortsatt fra kysten innover fjordene, men spredning fra byene langs kommunikasjonsveiene var mindre fremtredende. Vinteren 1918/19 opptrådte influensaen spredt og sporadisk, tilsynelatende uten bestemt spredningsmønster og rekkefølge. Jernbanen, hurtigruten og automobilrutene spilte trolig en viktig rolle i spredningsprosessen, spesielt andre halvår 1918. Ulik sosial interaksjon, for eksempel et marked som samlet store folkemengder, kan bidra til å forklare eksplosive utbrudd av influensa og diffusjon på lavt geografisk nivå.
\end{abstract}

\section{Mamelund S-E. The diffusion of influenza in Norway during the 1918-19 Pandemic. Nor J Epidemiol 1998; 8 (1): 45-58.}

\section{ENGLISH SUMMARY}

In 1918-1919, a world-wide pandemic, the Spanish Influenza, swept over the entire globe, killing at least 30 million people, most of them during the fall of 1918. A last, but small and less defined wave occurred in the winter of 1920. The first sporadic cases of Spanish Influenza in Norway are known from army camps in the early days of April 1918. More than three months later, the first scattered cases, clearly part of a pandemic wave, appeared in the capital of Kristiania, probably imported across the North Sea from Scotland. In the summer of 1918, influenza diffused rapidly along the coast towards northern Norway, from the coast to the inland along the fjords, and from the largest cities, centres of industry and commerce down the urban hierarchy to rural areas along major communication networks. During the autumn of 1918, influenza diffused much more slowly, this time probably from north to south, still from the coast and inland along the fjords, but outward diffusion from cities along communication networks was less prominent. In the winter of 1918/19, influenza occurred in a scattered way, apparently without any particular order or pattern of diffusion. Railways, coastal steamers and automobiles probably played an important role as agents for movement of disease carriers, especially during the second half of 1918 . Communal activities which brought susceptibles together during a critical period, for instance a large fair, provided excellent conditions for rapid spread of the disease. Such activities can help explain the many sudden and heavy outbreaks of influenza and diffusion pattern on a geographical micro level.

\section{INNLEDNING}

For 80 år siden ble vi rammet av en verdensomspennende influensaepidemi, en pandemi, uten sidestykke i historien. Over en milliard mennesker, det vil si mer enn halvparten av datidens befolkning, ble sannsynligvis angrepet, og minst 30 millioner mennesker døde
(Rice 1989). Pandemien ble tidlig kjent som «spanskesyken» ettersom mange trodde at sykdommen startet $\mathrm{i}$ Spania. Influensaen spredte seg i tre verdensomspennende bølger. «Sommerepidemien» startet 5. mars 1918, ikke i Spania, men sannsynligvis i Kansas, USA (Patterson og Pyle 1991). Sykdommen spredte seg raskt til Frankrike og resten av Europa med amerikan- 
ske soldater, og nådde Asia, Nord-Afrika og Australia i juli (Crosby 1989). I denne perioden var influensaen relativt mild med få dødsfall. «Høstepidemien» startet 22. august, muligens med opphav i Frankrike, Sierra Leone og USA (Ibid). I løpet av vinteren og våren 1918/19 blusset influensaen opp for tredje gang. En mindre influensabølge vinteren 1920 regnes også ofte som en del av spanskesyken (Åman 1990).

For verden under ett krevde spanskesyken minst tre ganger så mange liv i løpet av et snaut år som den fem år lange verdenskrigen (Wilton 1993). Til tross for dette er spanskesyken lite omtalt når perioden er behandlet av internasjonale historikere (Crosby 1989). Spanskesyken er også en «glemt» begivenhet i norsk sammenheng, som regel avspist med noen få standardlinjer i norske oppslagsverk og historieverk. Aarhus (1988:59) har kommentert historikernes «glemsel» på følgende måte: «Som dei tidligare karta innheld kvite felt, syntes dette å vere eit temmeleg kvitt felt, eit uutforska område i historisk samanhang». Det finnes ikke mye medisinsk litteratur om spanskesyken i Norge, og det som finnes ble stort sett publisert $i$ årene under og like etter epidemien. To relativt ukjente studier av Skajaa (1921) og Hansen (1923) er blant de viktigste forskningsbidragene på området. Den første er i all hovedsak en patologisk-anatomisk og bakteriologisk undersøkelse vedrørende spanskesyken, men den inneholder også et kapittel om sykdommens epidemiologiske utbredelse på Vestlandet, basert på utsendte spørreskjemaer til distriktslegene og stadsfysiki på Vestlandet. Den andre er en rendyrket epidemiologisk og demografisk studie av spanskesyken i Bergen, delvis basert på intervjudata. I tillegg til disse studiene finnes en rekke mindre artikler og notiser publisert i de største medisinske tidsskriftene fra 1918 til 1920. Ramberg (1969) har skrevet en oversiktsartikkel med referanser til arbeidene nevnt ovenfor. Melby (1955) og Harboe (1976) har også skrevet om spanskesyken, spesielt om influensaens epidemiologi.

To nyere studier har sett nærmere på de demografiske konsekvensene av spanskesyken i Norge. Mamelund og Borgan (1996) har vist at forventet levealder sank med i overkant av syv år for begge kjønn i 1918, fra 56,1 år for menn og 59,4 for kvinner i 1917, og at flest dødsfall oppsto i aldersgruppen 20-40. I en annen studie har Mamelund (1998) kommet frem til at 1,2 millioner nordmenn sannsynligvis ble angrepet, og at mellom 13 og 15 tusen døde, det vil si 5-6 dødsfall per 1000 innbyggere. Estimatet på syke og døde er hhv. tre ganger og dobbelt så høyt som de mest refererte som vi finner i norske oppslagsverk og historieverk (Fuglum 1988, Caplex 1997, Aschehoug og Gyldendals store ettbindsleksikon 1997).

Det finnes ingen omfattende spredningsstudier av historiske influensapandemier i Norge. I denne artikkelen skal jeg ta for meg spredning av influensa i Norge under spanskesyken 1918-1919. Følgende spørsmål vil stå sentralt: Hvor og når oppsto spanskesyken?
Hvem ble først rammet? Fulgte epidemien visse spredningsveier, rekkefølger og geografiske mønstre? Hvilken rolle spilte transport og kommunikasjonsnettverk i spredningsprosessen? Og: Hvilke faktorer kan bidra til å forklare lokal sykdomsspredning?

Internasjonale influensaforskerne hevder nå at tiden statistisk sett er overmoden for en ny stor pandemi. Horton (1996) spår for eksempel en ny verdensomspennende influensaepidemi i samme størrelsesorden som spanskesyken i nærmeste fremtid. Studier av influensaens geografi og historie kan være nyttig for offentlig helseplanlegging (Pyle og Patterson 1987). Resultater fra forskning på historiske pandemiers spredningsmønster og epidemiologi kan inngå som bakgrunnsinformasjon i risikoanalyser og beredskapsplaner for fremtidige pandemier.

\section{DATA OG METODE}

Denne artikkelen er i hovedsak basert på data fra de upubliserte og originale medisinalberetningene $(\mathrm{Mb})$ fra 1918 og 1919. Det finnes i alt 321 medisinalberetninger, én for hvert av landets legedistrikter i 1918 (Det Civile Medisinalvesen 1922, heretter forkortet DCM). De årlige medisinalberetningene er skrevet av distriktslegene og formålet med disse var å gi en statistisk oversikt over sykelighet og dødelighet og en beskrivelse av utvikling i levekår og hygiene. De amtvise statistiske oversiktene i de trykte medisinalberetningene, Sundhetstilstanden og Medisinalforholdene, utgitt av Det Civile Medisinalvesen, er basert på de originale medisinalberetningene. Medisinalberetningene fra Hedemarken amt (26) i 1918 og 1919 er dessverre kommet på avveie i Riksarkivet. Til alt hell er spanskesykens utbredelse i dette amtet spesielt fyldig behandlet i den trykte medisinalberetningen for 1918 (DCM 1922). Store deler av medisinalberetningene fra 1918 og 1919 er viet spanskesyken, og inneholder både kvantitative og kvalitative data som er egnet for å analysere epidemiens spredningsmønster. Rapportert sykelighet av influensa og lungebetennelse er for eksempel oppgitt for hver måned og kan brukes i matematiske spredningsmodeller for å analysere epidemiens varighet, omfang, form og spredningshastighet. I denne artikkelen skal jeg imidlertid analysere distriktslegenes empiriske beskrivelser om:

1. Første tilfelle av spanskesyken (indekstilfelle).

2 . Smitteimportørenes geografiske mobilitet, transportbruk og regionale spredningsmønstre generelt.

3. Sosial interaksjon i et lokalsamfunn, for eksempel et marked, som kunne bringe mottagelige individer sammen i en kritisk periode slik at enkelttilfeller kunne gå over i en større epidemi.

Det er ikke alltid gitt hva forfatterne av medisinalberetningene har regnet som første tilfelle. Dette kan skyldes at forfatteren refererer til sporadiske tilfeller som kan oppstå flere måneder før en pandemi bryter 
ut, første spredte tilfeller like før en pandemi bryter ut (invasjonsperiode), som også kan være forvekslet med annen sykdom, første tilfeller av en pandemisk bølge, eller inntrykk av sykelighet eller dødelighetstopper (Patterson 1985). Når det gjelder punkt 2 er spørsmål om forfatterens uavhengighet av sentral betydning:

Angaaende sygdommens utbredning geografisk var det ogsaa i det avsidesliggende Tysfjord, som overalt ellers i verden, paatagelig, hvordan den bredte sig med kommunikationsmidlerne, fra bygdenes mere centrale til de mere avsidesliggende, intill den sluttet - som epidemisk betraktet - ved de mindst sparsomt bebyggede fjorbuende (Mb. for Tysfjord 1918).

Angaaende sygdommens utbredelse synes den ogsaa her i distriktet at den fulgte kommunikationsveierne, idet den tydelig kan følges fra gaard til gaard (Mb. for Sande 1918).

Forfatterne av disse medisinalberetningene hadde tydeligvis oversikt over den gjeldende oppfatningen av spanskesykens spredningsmønster utenfor sitt eget legedistrikt. Disse og andre forfattere kan ha blitt påvirket av andres fremstillinger i tillegg til egne erfaringer. Det er også viktig å presisere at mangel på data fra et gitt legedistrikt ikke behøver å bety at sykdommen var fraværende her (for eksempel Mosjøen stadslegedistrikt). Gitt disse usikkerhetsmomentene, inkludert diagnoseproblemer, spesielt for sporadiske tilfeller eller tilfeller som oppsto i en tidlig fase av pandemien, må spanskesykens spredningsmønster som presenteres i denne artikkelen tolkes med forsiktighet.

\section{BEGREPER I GEOGRAFISKE SPREDNINGSSTUDIER}

I geografiske spredningsstudier (diffusjonsstudier) kan vi skille mellom fire spredningstyper: ekspansjon og relokalisering, som sier noe om spredningens form, og hierarkisk og kontagiøs spredning, som sier noe om spredningens karakter (Gould 1969, Meade et al. 1988). I denne sammenhengen er ekspansjonsdiffusjon den mest relevante tilnærmingen, siden relokaliseringsdiffusjon innebærer at spredningsfenomenet (spanskesyken) forlater opprinnelsesstedet gjennom personer som flytter. Folk på flyttefot er neppe de viktigste spredningsaktørene under en epidemi, selv om disse også kan spre smitte. I en ekspansjonsprosess blir spredningsfenomenet igjen på opprinnelsesstedet, ofte $i$ en forsterket utgave, ettersom stadig flere blir konfrontert med spredningsfenomenet gjennom kontakt, i dette tilfelle, mellom syke og ikke syke. Kontagiøs spredning blir også ofte kalt «kontaktdiffusjon», «nabodiffusjon», «bølgediffusjon» eller «epidemisk diffusjon». I fortsettelsen vil jeg kalle denne spredningstypen «nabodiffusjon». Denne prosessen er sterkt påvirket av avstand, fordi sannsynligheten for kontakt mellom «naboer» er større enn for kontakt mellom folk som bor langt unna hverandre i geografisk forstand. Geografisk avstand betyr ikke alltid like mye for en diffusjonsprosess. Noen sprednings- fenomen kan for eksempel «hoppe over» mellomliggende individer og steder. Dette kjennetegner hierarkisk diffusjon der større steder får sykdommen først, mens perifere områder får den senere, det vil si vertikal nedgående diffusjon (Gould 1969). Slike spredningsmønstre oppstår fordi geografisk avstand mellom mennesker som bor på store steder er relativ som følge av at kommunikasjonsnettverk ofte er best utbygd mellom store steder. Kontakthyppigheten mellom store byer er derfor større enn den faktiske geografisk avstanden skulle tilsi. I tillegg til vertikal nedadgående diffusjon, kan fenomenet også spres oppover i et hierarki og dessuten horisontalt, dvs. mellom steder på samme hierarkiske nivå.

I spredningsstudier er det også viktig å identifisere spredningsnettverk, det vil si de kanaler som formidler forflytting av sykdomsbærere gjennom tilgjengelig transportnettverk (Morill og Dormitzer 1979). Kartlegging av kontaktmønster hører også med her. Spredningsbarrierer er det motsatte av spredningskanaler, og kan forsinke og forme en spredningsprosess. Vi kan skille mellom tre barrierer (Meade et al. 1988): En befolkning som er vaksinert eller har opparbeidet immunitet mot influensa er et eksempel på en absorberende barriere, det vil si at isolerte influensatilfeller hindres $\mathrm{i}$ å spres videre. Det å bo relativt isolert og spredt innerst i en fjordbygd, oppe på fjellet eller i en bondebygd $\mathrm{i}$ innlandet, kan fungere som en gjennomtrengelig barriere, det vil si at de fysiske forholdene tillater spredning, men forsinker prosessen. Reflekterende barrierer kanaliserer og forsterker virkningen av en lokal spredningsprosess ved å blokkere spredning til andre steder: Streng karantenestrategi, for eksempel på et øysamfunn, kan hindre smitteimport og kanalisere sykdom til andre steder uten slike tiltak. Frivillig isolasjon på grunn av smittefrykt skapt av media, familie og venner kan sammen med de fysiske barrierene forsinke spredningsprosessen ytterligere (Shannon og Pyle 1989).

De fleste diffusjonsprosesser vil ikke passe helt og holdent innenfor én og samme kategori, og de kan foregå med varierende hastighet gjennom et hierarki av nettverk på ulike geografiske nivåer. I virkeligheten vil derfor en diffusjonsprosess formes og struktureres gjennom kombinasjoner av de forskjellige diffusjonstypene, der en av dem kan være viktig i en tidlig fase, mens en annen kan være viktig i en senere fase. Tradisjonell geografisk tilnærming til diffusjon er ofte bedre egnet for å beskrive et spredningsforløp, dvs. form, struktur og retning, enn å forklare hvorfor et gitt spredningsmønster oppsto. En god og riktig beskrivelse kan dog danne grunnlag for en god forståelse av et spredningsforløp. Dersom vi har ambisjoner om å forklare spanskesykens spredningsmønster, må vi imidlertid supplere tradisjonelle geografiske tilnærminger med analyser av spredningsfenomenets rammebetingelser, for eksempel betydningen av sosial interaksjon for lokal sykdomsspredning. 
I denne artikkelen antar jeg, i likhet med Cliff et al. (1986), at influensa spres fra person til person ved luftbåren dråpesmitte. Dette betyr at jeg ser bort i fra at influensa også kan spres mellom fugler, svin og mennesker, og at latent influensa kan aktiveres under visse sesongmessige betingelser ${ }^{1}$.

\section{RESULTATER OG DISKUSJON}

\section{De forste sporadiske tilfellene}

De første sporadiske tilfellene av spanskesyken i Norge ble rapportert 3. april 1918 (Lorentzen og Sørdahl 1988, Thuesen 1997). I løpet av den første uken i april ble det sykmeldt 6000 mennesker her i landet, men det er usikkert om dette skyldes influensa. Den offisielle influensastatistikken for april viser nemlig ingen oppgang i antall rapporterte tilfeller, men derimot en kontinuerlig nedgang siden januar (DCM 1922). Et mistenkelig høyt antall influensatilfeller oppsto imidlertid i norske militærleire i april, og bekrefter forsåvidt at noe var i gjære (Hoyle 1968). På dette tidspunktet tok ingen særlig notis; influensa, luftveisinfeksjoner og forkjølelsessykdommer var tross alt normalt for denne årstiden. Aprilutbruddet ble således ikke nevnt i det hele tatt i de medisinske tidsskriftene eller i avisene. Den første informasjonen om spanskesyken i utlandet kunne man lese i norske aviser 28. mai 1918. Reuter telegrambyrå kunne da fortelle fra Madrid at

Kongen, førsteministeren og flere andre ministre er blevet syge. De lider af en mystisk sygdom, som har optraadt over hele landet og har angrebet $30 \%$ av befolkningen. Sygdommen ansees ikke for at være farlig (Aftenposten 28. mai 1918).

De første notisene om spanskesyken i Norge kom først i midten av juli i de medisinske tidsskriftene. Disse og andre deler av litteraturen, deriblant medisinalberetningene, tidfester stort sett starten på spanskesyken til midten av juni eller begynnelsen av juli (DCM 1922). De som sier at spanskesyken startet i midten av juni refererer som regel til de første spredte tilfellene av invasjonsperioden, mens de som hevder at den startet $\mathrm{i}$ juli, refererer til spanskesykens eksplosive masseutbrudd.

Enkelte sporadiske og alvorlige influensatilfeller i Norge og verden for øvrig i 1917, settes også ofte i forbindelse med spanskesyken. Sporadiske influensatilfeller, såkalt «pre-seeding», oppstår ofte i forkant av en pandemi (Kilbourne 1975). Det er derfor ikke uvanlig at en pandemi kan ligge og «ulme» i flere måneder før den bryter løs for alvor. Som vi skal se nedenfor, gikk det over tre måneder før spanskesyken brøt ut for

\footnotetext{
${ }^{1}$ Det som først og fremst karakteriserer pandemisk influensa er at den sprer seg raskt. Dette skyldes trolig en kombinasjon av influensaens korte inkubasjonstid, at mange syke fortsetter daglige gjøremål og smitter andre, at størsteparten av befolkningen mangler immunitet og at influensa er en sykdom som lett overføres fra person til person (Vaughan 1921).
}

fullt i Norge etter de første sporadiske tilfellene, til tross for at en hel befolkning av mottakelige individer sto til disposisjon for det nye influensaviruset. Vi har ikke opplysninger om hvor i landet de første sporadiske tilfellene oppsto, men som vi har sett ble det rapportert om sykdom blant annet i militærleire. Det er ikke vanlig at influensa spres videre til bredere lag av befolkningen i slike latente perioder. Dette skjedde heller ikke i Norge våren 1918.

\section{Sommerepidemien}

Hansson (1919) hevder at spanskesyken startet i midten av juni, og at Norge sannsynligvis ville fått epidemien allerede i mars dersom vi ikke hadde passvanskeligheter i forbindelse med krigen. Ustvedt (1919) tror at spanskesyken kan ha kommet til Norge fra Murmansk via Glasgow, hvor den var rapportert i mai. Denne importveien kan ikke ha vært blant de viktigste ettersom Murmanskkysten og Enare ikke ble rammet av spanskesyken før vinteren 1919 og vinteren 1920 (Hansen 1923, Vahtola 1994). Dessuten raste epidemien som verst på den norske siden av grensen, $\mathrm{i}$ Syd-Varanger, allerede i juli og august 1918 (Mb. for Sydvaranger 1918). Som vi skal se senere, kom antagelig spanskesyken til Nord-Norge med hurtigruten fra Sør-Norge (figur 1). Det er likevel ikke umulig at spanskesyken kom til Norge fra Skottland, som sannsynligvis fikk importert sykdommen med soldater fra Frankrike (Vaughan 1921). Skajaa (1921:17) hevder også at:

Man kan vistnok gaa ut fra, at influenzaen kom til Norge fra Vest-Europa, idet epidemien opptraadte i Kristiania tidligere end i baade Kjøbenhavn, Gøteborg og Stockholm. Vi skulde da ha ventet, at epidemien var begynt i Bergen, ti som forholdene da laa an, under krigen, gik hovedveien fra Vest-Europa til Norge gjennem Bergen. Sandsynligvis har imidlertid influenzaen i denne pandemi, likesom i de to tidligere ægte pandemier (1837 og 1889), gjort sin intrædelse i landet gjennem Kristiania.

Skajaa har trolig rett i at spanskesyken ikke ble innført til Norge via Bergen, og at Kristiania var utgangspunkt for smittespredningen i Norge og Norden (figur 1$)^{2}$. De første spredte tilfellene i Kristiania oppsto nemlig 15. juni, mest sannsynlig etter smitteimport fra Skottland over Nordsjøen, mens de første spredte tilfellene i Bergen oppsto omkring jonsok (Great Britain Ministry of Health 1920, Vaughan 1921, Hansen 1923, Nordlander 1932, Patterson og Pyle 1991).

\footnotetext{
${ }^{2}$ De aller første spredte tilfellene i Sverige oppsto i Skåne 23. juni, mens de første tilfellene av den første epidemibølgen i Stockholm oppsto 6. juli, begge etter smitteimport fra Kristiania (Nordlander 1932, Åman 1990). Det er også sannsynlig at spanskesyken spredte seg fra Norge til Sverige via jernbanelinjen Trondheim-Storlien-Östersund $\mathrm{i}$ begynnelsen av juli (Åman 1990). De første tilfellene under den første epidemibølgen i København oppsto andre uken i juli (Great Britain Ministry of Health 1920).
} 
Det finnes ingen holdepunkter for at spanskesyken kom til Bergen sjøveien til tross for at havnen var en av verdens mest trafikkerte (Hansen 1923). Ingen sjøfolk ombord på fartøyer som skulle konvoieres over Nordsjøen eller andre passasjerer var blant de tidligst angrepne. Mest sannsynlig er det derfor at spanskesyken kom til Bergen med jernbanen fra Kristiania (figur 1 og 3). De første rapporterte sykdomstilfellene i Kristiania og Bergen ble mottatt av de respektive helserådene 29. juni og 3. juli (Kristiania sundhetskommision 1919, Hansen 1923). I Bergen ble man ikke klar over at man sto ovenfor en tilsvarende epidemi som i Kristiania før 6. juli. Disse rapportene er basert på de første tilfellene under sommerbølgen, og oppsto derfor noe senere enn de første spredte tilfellene før denne brøt ut for fullt.

De neste spredte tilfellene etter Kristiania oppsto 17. juni og 23. juni på to av marinens panserskip, «Norge» og «Eidsvold», som var stasjonert langs Nordsjøkysten fra Kristiansand til Jærens Rev, det vil si ved Mandal, Farsund, Flekkefjord, Egersund og Marviken (Keyser 1918, Speilberg 1918, Sørensen 1998). Mannskapet ombord i disse panserskipene var $i$ utstrakt kontakt med resten av Europa under krigen. Mest sannsynlig er det at smitten ble overført etter kontakt med engelske marinefartøyer (Nordlander 1932, Patterson og Pyle 1991). Spanskesyken spredte seg imidlertid ikke nevneverdig videre til den norske sivilbefolkningen, muligens med unntak av i Oddernes, hvor de første spredte tilfellene ble kjent 20. juni (Mb. for Oddernes 1918). Dette kan skyldes at skipene ble satt i karantene og at eventuelt hjemsendte ikke hørte hjemme ved de nevnte basene. I de påfølgende dagene og den siste halvdelen av juni ble det også observert spredte influensatilfeller på Løten, Elverum, Tynset og Tolga, alle etter smitteimport med folk som hadde vært på St. Hans-marked i Kristiania (DCM 1922). I flere andre legedistrikter, blant annet Karlsøy i Troms, Fosen, øst for Bergen langs Bergensbanen, Jevnaker og Gran i Kristians amt (Oppland), Vinje og Tinn i Bratsberg amt (Telemark), ble det også observert spredte tilfeller i juni (figur 2). Foruten sannsynlig smitteimport til Norge fra Skottland og England i juni, ble det påvist ekstern sykdomsintroduksjon fra Finland (til Grytten) og Amerika (til Davik og Buvik i SørTrøndelag) i juli, og sannsynligvis fra Sverige til Lierne og Trondheim i oktober ( $\mathrm{Mb}$. for de nevnte legedistriktene 1918).

De første tilfellene under sommerepidemien ble stort sett registrert i de største byene langs kysten eller i sterkt trafikkerte, tett befolkede og sentrale industrisentra både langs kysten og i innlandet (Skajaa 1921, DCM 1922). Legene trodde at sykdommen ville få problemer med å spre seg videre utover landet og at

\footnotetext{
${ }^{3}$ I 1916-17 overgikk kun havnen i New York Bergen når vi ser på tonnasje, men når det gjelder ankomst og avgang var Bergen størst (Bergen Børs Årbok 1918, som sett i Hansen 1923).
}

den vesentlig ville herje i byene. Mange bygdesamfunn ble spart for sommerepidemien som i hovedsak ble observert blant feriereisende fra byene, på hotellene, pensjonatene, dampskipene, havneområdene og jernbanestasjonene med deres nærmeste omgivelser (DCM 1922). Dårlig utbygd kommunikasjon utover bygdene og isolasjon på grunn av smittefrykt kan bidra til å forklare dette. En stund så det derfor ut som om legene skulle få rett. Senere skulle det vise seg at de geografiske barrierene var gjennomtrengelige, og at de kun forsinket smittespredningen. Folk i mindre byer, spredtbygde og avsidesliggende strøk på landsbygda, ble stort sett smittet på sensommeren eller utover høsten, gjerne etter besøk i, eller besøk fra de største byene, for eksempel Kristiania, Bergen, Trondheim, Bodø og Tromsø (figur 1). Spanskesyken spredte seg med kystseilere fra Kristiania langs Skagerakkysten og opp til Stavanger, fra Sør-Norge til Nord-Norge langs kysten, fra Tromsø til Svalbard og Bjørnøya, fra kysten innover fjordene på Vestlandet og i NordNorge, og fra byene og industrisentra utover bygdene langs de viktigste kommunikasjonsveiene. Jernbanen, hurtigruten og lokalbåttrafikk spilte trolig en viktig rolle i denne prosessen.

Eksplosiv utvikling av influensa under den primære pandemien, det vil si den første influensabølgen, skyldes trolig relativt godt utbygd kommunikasjonsnettverk som la forholdene til rette for rask smittespredning:

Dog viser studiet av epidemiernes gang, at sygdom-
men ingensteds utbrer sig hurtigere end samfærdsels-
midlerne gjør det mulig. Jo hurtigere og rikeligere
disse efterhvert er blit, desto hurtigere har sykdommen
ogsaa formaad at utbrede seg. Større byer med livlig
samfærdsel angripes før steder, hvor samfærdselen er
mindre livlig. Tynt befolkede distrikter angripes sent.
Utbredningen sker som regel radiært, men av og til
ogsaa sprangvis (Schønfelder 1919:309).

Spanskesyken i Hardanger er godt egnet for å beskrive spredningsmønsteret under sommerepidemien. De første sykdomstilfellene oppsto i andre uken av juli og kan tilskrives bestemte personer som tok med seg smitten langs hovedkommunikasjonsveiene Indre Hardanger-Utne-Aalvik, Bergen-Ytre Hardanger-Aalvik og Voss-Eide-Aalvik. (Keyser 1918, Mb. for Ulvik 1918). Epidemien spredte seg deretter raskt innover Hardangerfjorden før den endte opp i fjellbygden Røldal, to til tre uker etter at de første tilfellene ble observert i Bergen og på Voss (Skajaa 1921, Mb. for Ullensvang 1918). At Odda fikk sykdommen før Tyssedal, til tross for at sistnevnte ligger lenger ute $\mathrm{i}$ fjordarmen enn forstnevnte, skyldes trolig at kontakten med andre steder var større her, det vil si et eksempel på hierarkisk diffusjon. Dampbåttrafikken spilte sannsynligvis en ikke ubetydelig rolle i smittespredningen fra ytre til indre Hardanger.

Til tross for livlig kontakt mellom øyene i kystNorge, og øyene og fastlandet, herjet sykdommen ofte på et utvalg av øyene og på fastlandet, mens naboøye- 
Figur 1. Kjente spredningsveier av influensa i Norge under spanskesyken 1918-1919.

Kilde: Morske Medisinalberetninger 1918 og 1919, Ustvedt 1919, GMH 1920, Vaughan 1921, Skajaa 1921, DCM 1922 og 1923 , Hansen 1923, Nordlander 1932, Åman 1990, Patterson og Pyle 1991. Tegning: Liv Hansen (SSB).
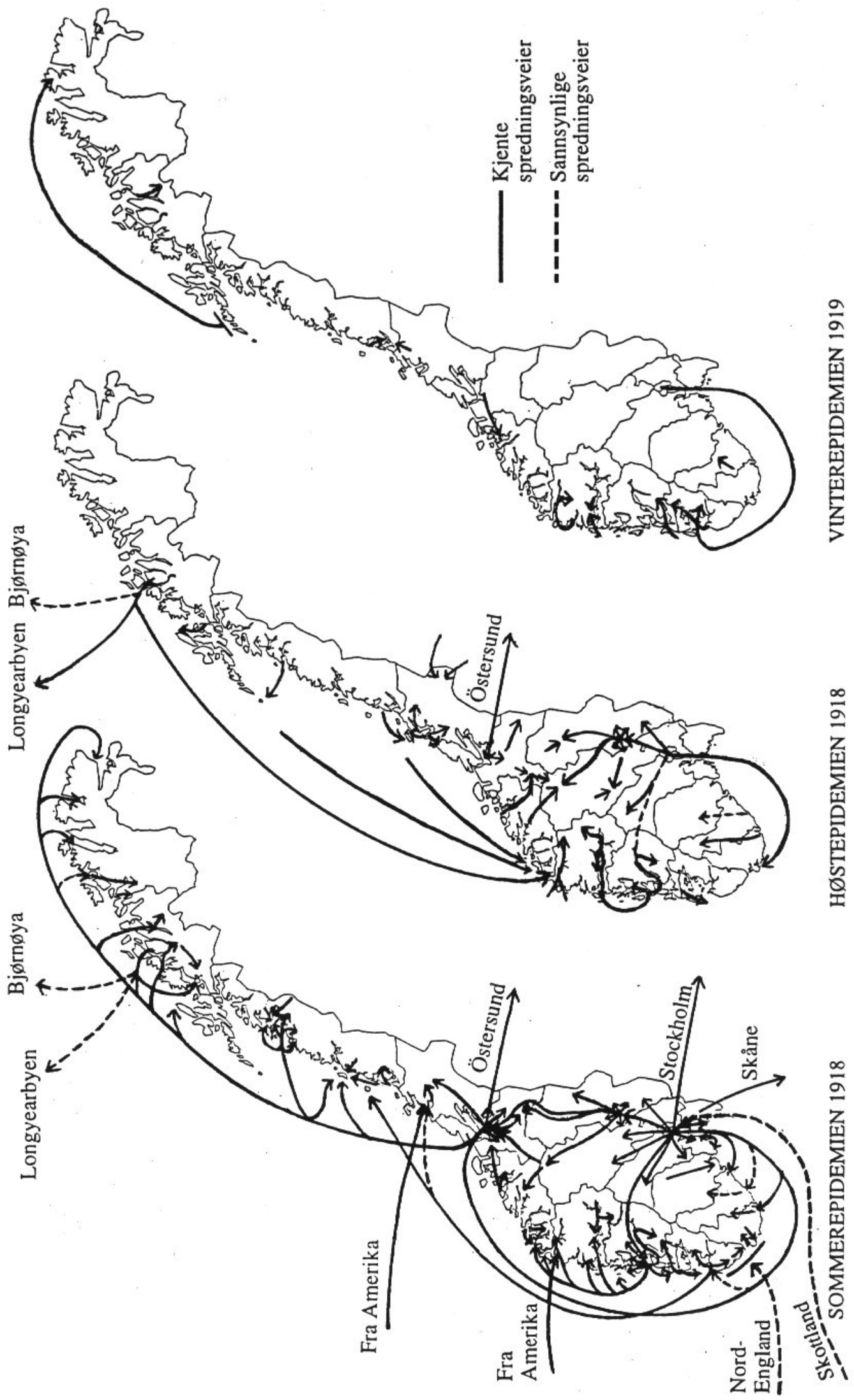


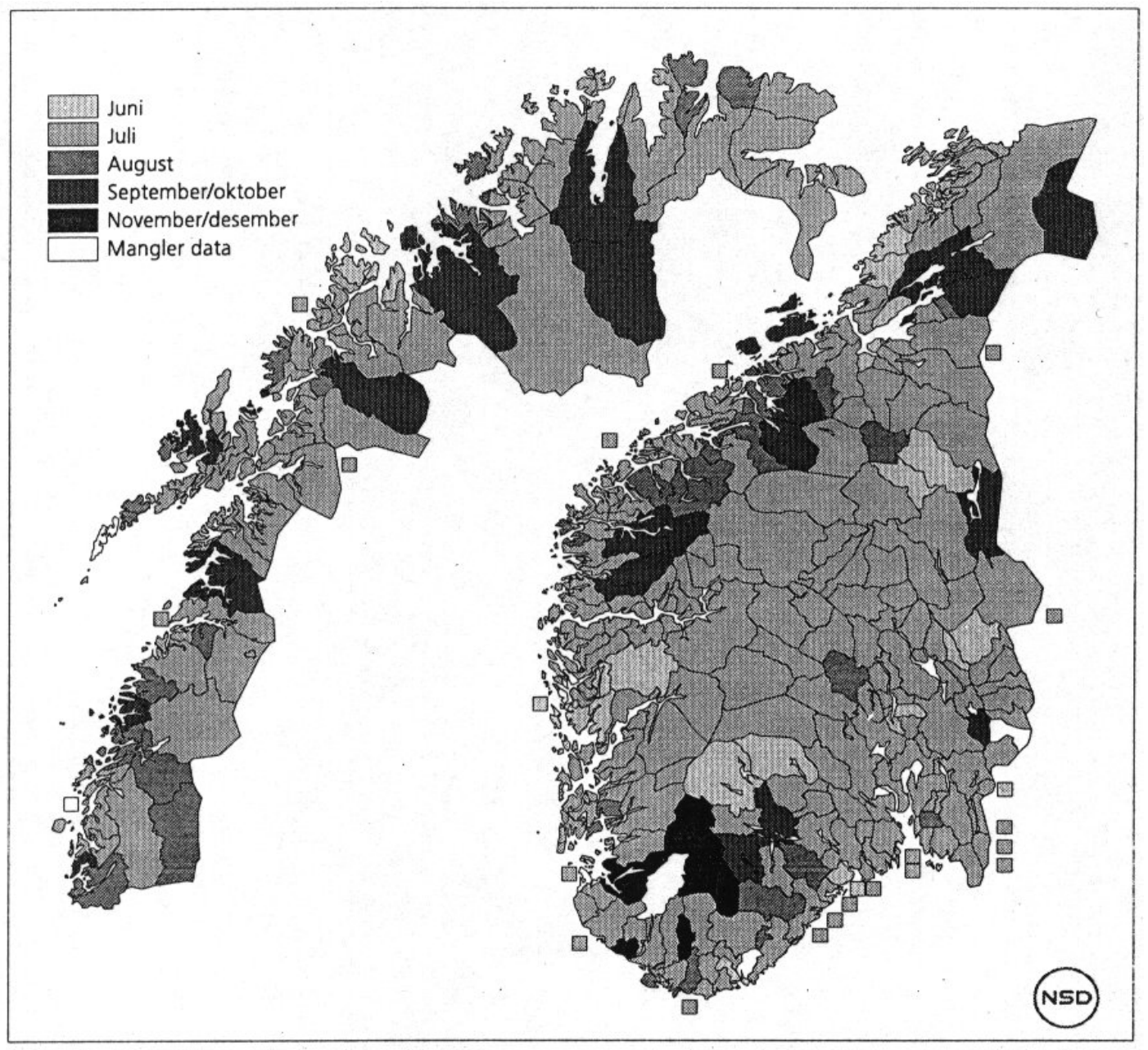

Figur 2. Første opptreden av spanskesyken i Norge andre halvår 1918. Kvadratene som omkranser kartet representerer landets byer.

Kilder: Bearbeidete data fra de originale medisinalberetningene fra 1918 og 1919, Riksarkivet i Oslo.

ne kunne gå fri. Det samme skjedde på flere av fyrene langs kysten (Sande og Herøy 1918, Skajaa 1921, DCM 1922, Hansen 1923). De fleste av øysamfunnene som unnslapp sommerepidemien ble imidlertid rammet høsten 1918. Indre deler på Sørvestlandet, for eksempel Bygland og Valle i Setesdalen, Lyngdal, Sokndal, Røldal, Hægebostad, Kviteseid og Fyresdal unngikk også sommerepidemien, muligens med unntak av de mest sentrale gårdene (figur 2). Det samme skjedde i Lierne i Nord-Trøndelag og Kistrand og Karasjok i Finnmark. Befolkningen i disse legedistriktene ble rammet $\mathrm{i}$ oktober, så nok en gang var det bare snakk om en utsettelse. De indre fjorddistriktene på Nordvestlandet, indre Trondheimsfjorden, indre kyst og innlandsdistrikter nordover til Finnmark, fikk alle spanskesyken noe senere enn de ytre fjorddistriktene og kystdistriktene langs den samme strekningen (figur 2). Få, om noen, steder unnslapp spanskesyken totalt i årene 1918-1920. Fjellgrenda Lykkja, som ligger isolert mellom Hemsedal og Valdres, kan være ett av unntakene (Mb. for Gol 1918, DCM 1923).
Sommerepidemien forsvant nesten like raskt som den kom, og etter to til fire ukers tid var det hele stort sett over (Skajaa 1921). I Kristiania kulminerte epidemien allerede andre uken $\mathrm{i}$ juli, mens epidemien $\mathrm{i}$ byene på Vestlandet, som fikk sine forste tilfeller noe senere enn i Kristiania, kulminerte i slutten av juli (Kristiania Sundhetskommision 1919, Skajaa 1921). På landsbygda ble det ikke alltid noen bestemt kulminasjon ettersom befolkningen i nye grendesamfunn ofte ble angrepet rett før man trodde det hele var over. Av denne grunn kan det se ut som enkelte legedistrikter erfarte én kontinuerlig influensabølge andre halvår 1918. De fleste steder opplevde likevel at influensaen kom i to bølger i 1918, én på sommeren og én på høsten, og at en tredje influensabølge blusset opp vinteren 1918/19 (DCM 1922).

\section{Hostepidemien}

Spanskesykens andre influensabølge, «høstepidemien» viste seg noen steder allerede i slutten av august og i månedsskiftet august-september, deriblant i Narvik, 
Bodø, Trondheim, Skogn, Kristiansund, Ålesund, Sande, Herøy og Ulstein $(\mathrm{Mb}$. for de nevnte legedistriktene 1918). Et gjennomgående trekk var at jo lenger sørover man kom i landet, både langs kysten og i innlandet, desto senere inntraff høstepidemien. På store deler av sørvestlandet fra Åmli i nordøst, Skudeneshavn i nordvest, til Farsund lengst i sør, skjedde dette i november og til og med så sent som i midten av desember. Om dette var en tilfeldighet, eller om høstepidemien virkelig spredte seg sørover, er usikkert (Skajaa 1921). Den andre influensabølgen startet like tidlig på bygdene som i byene; bygdene ble like hardt rammet som byene og spredning fra byene var mindre fremtredende. Den geografiske utbredelsen kunne derfor i mindre grad føres tilbake til bestemte sentra (figur 1). Smitten spredte seg saktere enn under sommerepidemien, og i mange områder kunne sykdommen følges fra person til person og fra sted til sted. Dette kan trolig forklares ved at gjennomgått sykdomsforløp ga immunitet mot senere utbrudd (Skajaa 1921, Hansen 1923). Høstepidemien varte lenger, to til tre måneder, og krevde atskillig flere menneskeliv enn sommerepidemien. I Narvik, Bodø, Trondheim, Kristiansund og Ålesund kulminerte den andre influensabølgen allerede $\mathrm{i}$ september, $\mathrm{i}$ de fleste andre byene $\mathrm{i}$ slutten av oktober, mens Stavanger, Kristiansand og Arendal måtte slite med høstepidemien til november. Dersom høstepidemien virkelig spredte seg sørover, er ikke dette spesielt overraskende. Skajaa (1921:33) har også påpekt at:

Utbredelsen langs kommunikationslinjerne, som er saa fremtrædende i de primære pandemier, synes $\mathrm{i}$ efterepidemierne at spille en mere underordnet rolle, hvad der gir sig utslag i deres langsommere, mindre sprangvise fremadskriden, hvorunder storbyerne og trafikcentrene ikke angripes før andre lokaliteter, likesom sterkt trafikerede strøk kan gaa helt fri, selv om epidemien herjer i nærheten.

Eksempler på at høstepidemien mange steder startet tidligere på bygdene enn i byene, at den ikke alltid fulgte ferdselsårene og at tettbygde strøk kunne gå fri lenge selv om epidemien herjet $\mathrm{i}$ nabobygdene, har vi flere av. I Nordland forteller tre av distriktslegene om et slikt spredningsmønster. I Vik spredte for eksempel sykdommen seg med «merkelige hop ibland», slik at den tettbygde Vik-grenden nesten gikk fri i første omgang, og i Bindal spredte spanskesyken seg «med adskillige hop ibland og tok ikke saa uro med sig overalt» (Mb. for Vik og Bindal 1918). I Hattfjelldal hoppet høstepidemien også over enkelte tettbebyggelser der store deler av befolkningen ofte var samlet, mens de første tilfellene ble konstatert på avsidesliggende gårder med lite samkvem med resten av distriktet (Mb. for Hatfjeldal 1918). Tilsvarende spredningsmønster ble også observert i Stavanger amt. Spanskesyken blusset nemlig tidligere opp i distriktene omkring Stavanger enn i selve byen, som selv fikk flere sykdomstilfeller i siste halvdel av oktober (Mb. for Hjelmeland 1918 og 1919). Det beste eksemplet på at sykdommen ikke fulgte kommunikasjonsveiene $i$ samme grad under høstepidemien, finner vi kanskje i Lyngdal:

Man maatte nemelig da ha ventet at bygdernes centrum, «dalen», var blevet angrepet først og at sykdommen derfra utbredt sig opover i dalførene og derfra igjen til heigrendene. Derimot har vi her seet det omvendte billede, idet centrum saa sent som i januar er blevet angrepet, medens sykdommen først viste sig paa heigrendene (Mb. for Lyngdal 1918).

\section{Vinterepidemien}

I slutten av desember 1918 og i begynnelsen av januar 1919 blusset en tredje influensabølge opp, som kulminerte i mars for landet som helhet. Denne bølgen opptrådte spredt og sporadisk, gjerne på de mest avsidesliggende gårdene og grendene, og tilsynelatende uten bestemt spredningsmønster og rekkefølge (figur 1). Skajaa (1921:25) mener at «forklaringen herpaa er øiensynlig, at det især er gaarder og grender, som tidligere er gaat fri, som nu angripes». Vinterepidemien $\mathrm{i}$ Herøy legedistrikt hadde for eksempel «ikke nogen bestemt utbredning, men opptraadte i spredte grupper snart her snart der blandt folk som ikke hadde hat den før» (Mb. for Herøy 1919). Vi har også eksempler på det motsatte. I Skaanevik spredte sykdommen seg etter samme mønster og rekkefølge som sommeren 1918: «Sykdommen utviklede og utbredte sig fra sted til sted, væsentlig fra vest til øst, med flest tilfælde i april maaned» (Mb. for Skaanevik 1919). Sommeren og høsten 1919 var det få epidemier, men utover høsten var det enkelte isolerte tilfeller, såkalte husepidemier, hvor enkelte familier eller deler av familier som ikke var rammet tidligere, ble syke. I slutten av 1919 blusset influensaen ondartet opp igjen en kort periode, spesielt i Vadsø by, Syd-Varanger, Leinstrand, Bjugn og Børsa (DCM 1923). En fjerde, mindre definert influensabølge, igjen dominert av isolerte tilfeller, blusset opp i januar 1920, med kulminasjon i februar.

Blant distriktslegene var det en utbredt oppfatning at spanskesyken spredte seg med kommunikasjonsmidlene, spesielt jernbanen og hurtigruten, og at tilreisende turister, forretningsfolk og andre passasjerer førte smitten med seg (DCM 1922). Jernbaneansatte, telegrafister, skysskaffere, havnearbeidere og deres familier var derfor også blant de første som ble angrepet. Det samme skjedde med folk som bodde i og i nærheten av stasjonssamfunnene, havnene og overnattingsplassene.

\section{Hurtigruten og spredning fra Sor-Norge til Nord- Norge}

Sommeren 1918 spilte trolig hurtigruten en viktig rolle som transportør av sykdomsbærere sørfra til de største anløpshavnene og kommunikasjonsknutepunktene i Nordland, Troms og Finnmark (Mb. for Bodin, Dvergberg, Balsfjord og Salangen, Lyngen, Kjelvik, Tana, Vadsø 1918). Herfra fulgte smitten passasjerer over på lokalbåtene som brakte sykdommen videre innover 
fjordarmene til mindre anløpshavner og derfra utover innlandsbygdene $(\mathrm{Mb}$. for Brønnøysund, Hemnes, Herøy, Sandnessjøen, Verøy, Alta 1918). Dette spredningsmønsteret er et eksempel på hierarkisk diffusjon, hvor de største hurtigrutehavnene fikk spanskesyken først, mens lokalbåthavnene fikk den senere. Hurtigruten viste seg å være en meget rask spredningsagent, det gikk nemlig mindre enn to uker fra helserådene $\mathrm{i}$ Kristiania og Bergen fikk de første rapportene om spanskesyken, til det samme skjedde i Nord-Norge. Dette er i nærheten av maksimal spredningshastighet ettersom hurtigruten, som gikk fra Trondheim til Kirkenes og fra Bergen til Hammerfest, hhv. to og tre ganger i uken, begge brukte seks dager på reisen (Gram 1918). Handelsforbindelsene har historisk sett vært sterkere mellom Nord-Norge og Bergen enn mellom Nord-Norge og Trondheim (Brochman 1936). De fleste indekstilfellene i Nord-Norge kom derfor sannsynligvis fra Bergen og ikke Trondheim. Spredning langs landeveien forekom sannsynligvis i liten grad mellom Trøndelagsamtene og Nord-Norge (figur 1). Dette kan forklares på bakgrunn av tradisjonelt begrenset kontakt mellom trøndere og nordlendinger. Spanskesyken spredte seg også raskt fra fastlandet til Svalbard og Bjørnøya, hhv. 7. juli og 23. juli, med dampskip som kom fra Tromsø (Hansen 1923, Hoel 1966, 1967). Høstepidemien på Svalbard og Bjørnøya startet hhv. 24. september og 10. oktober, også denne gangen etter smitteimport med dampskip som sannsynligvis kom fra Tromsø.

\section{Jernbanens betydning for spredning i Sor-Norge}

I Sør-Norge spilte trolig jernbanen en like viktig rolle i sykdomsspredningen som hurtigruten fra Sør-Norge til Nord-Norge. Av plasshensyn skal jeg konsentrere meg om Rørosbanen, Dombåsbanen og Bergensbanen. Rørosbanen var sannsynligvis en viktig spredningskanal for spanskesyken fra Kristiania i sør til Sunnan nord for Steinkjer (figur 1). De første tilfellene, både under sommer og høstepidemien, ble i hvert fall rapportert på og omkring jernbanestasjonene ( $\mathrm{Mb}$. for Singsaas, Skogn 1918, DCM 1922). Stasjonssamfunnene like sør for Trondheim fikk trolig innført sykdommen både med passasjerer fra Trondheim og med passasjerer sørfra (Mb. for Leinstrand, Melhus 1918). Spanskesyken spredte seg også muligens fra Trondheim til Sverige via jernbanelinjen Trondheim-Storlien-Östersund (Åman 1990). At Meråker fikk sykdommen senere enn Stjørdal støtter denne antagelsen (Krogstad 1987). I løpet av høsten 1918 kan denne spredningskanalen ha virket begge veier (figur 1). Dette spredningsmønsteret er også kjent ved tidligere epidemier av smittsomme sykdommer i Trondheim (Brochman 1936). De fleste epidemiene i Trondheim har blitt importert landeveien fra Østlandsbygdene eller Sverige, snarere enn sjøveien. Kystimport var sannsynligvis også av mindre betydning i Trondheim under spanskesyken. Det finnes $i$ hvert fall få holdepunkter for å hevde det motsatte.
Dombåsbanen var sannsynligvis en sentral spredningskanal for spanskesyken opp gjennom Gudbrandsdalen og over Dovrefjell til Trondheim (figur 1). Sommerepidemien holdt seg stort sett til tett befolkede områder rundt jernbanestasjonene og pensjonatene, og de første tilfellene ble som regel oppdaget blant jernbanearbeidere eller passasjerer som kom fra Kristiania (Mb. for Faaberg, Gausdal, Øyer Ringebu, Sel og Heidal, Lesja, Opdal 1918). Blant anleggsarbeidere som lå rundt på gardene $\mathrm{i}$ forbindelse med utbygging av Raumabanen ble det også tidlig rapportert om sykdom (Brev fra Lesja Historielag 1998). De første rapportene om utbredt sykdom utover bygdene i Gudbrandsdalen kom først i midten av oktober (Teigum 1975). Fra jernbanestasjonene på Hadeland, Toten, Land og Valdres spredte spanskesyken seg derimot raskt utover bygdene (DCM 1922).

Da Bergensbanen ble åpnet i 1908 sto en ny kanal klar for spredning av smittsomme sykdommer mellom øst og vest. I juli 1918 var det mulig å følge spredning av spanskesyken gjennom Hallingdal på vei fra Kristiania i øst til Bergen i vest (figur 3). Også her holdt sykdommen seg i begynnelsen til jernbaneansatte, feriereisende og hotellene. De første tilfelle blant bygdefolk ble ikke rapportert før 22. juli. Fra de første sykdomstilfellene ble kjent på jernbanestasjonen i Gol, til det samme skjedde på Finse, gikk det i overkant av en uke (Hansen 1923, Mb. for Gol, Aal 1918). Dette spredningsmønsteret er et eksempel på nabodiffusjon. At spanskesyken var konstatert på Voss, Trengereid og i Bergen før første tilfelle ble kjent på Ål, kan i denne sammenhengen forklares med at passasjertrafikken var mye større på disse stasjonene enn på Ål, det vil si et eksempel på hierarkisk diffusjon $(\mathrm{Mb}$. for Bruvik, Voss 1918). Til tross for at Gol ligger nærmere Kristiania enn både Ål og Geilo, og har flere ankomne passasjerer enn Ål, kom ikke spanskesyken hit først.

Disse eksemplene viser at man må være forsiktig med å generalisere om nabospredning. Stasjonsbyene Trengereid, Vaksdal og Dale fikk sannsynligvis spanskesyken fra Bergen:
Ogsaa denne gang kunde man iakttage at sygdom- men fulgte kommunikationsmidlerne idet de første tilfælde optraadte paa Vaksdal og derpaa i Fabrik- stedet Dale altsaa per jernbane - og altid kunde jeg iakkta ogsaa ved den senere opdukkende og mere ondartede epedemi fra begyndelsen av oktober til ut $i$ december maaned at sygdommen fulgte kommunika- tionsmidlerne, altsaa per jernbane eller dampskib idet de første tilfælder ofte skyldes at vedk. hadde været i Bergen og enten paa veien eller umiddelbart efter hjemkomsten ble syk (Mb. for Bruvik 1918).

Dette spredningsmønsteret kan, dersom vi ser på Søndre-Bergenhus amt (Hordaland) isolert, tolkes som nabodiffusjon, eller hierarkisk diffusjon dersom vi antar at sykdommen kom fra Kristiania, spredte seg til Bergen, hoppet over Dale, Vaksdal og Trengereid i første omgang, før den i andre omgang «gikk» tilbake østover. 


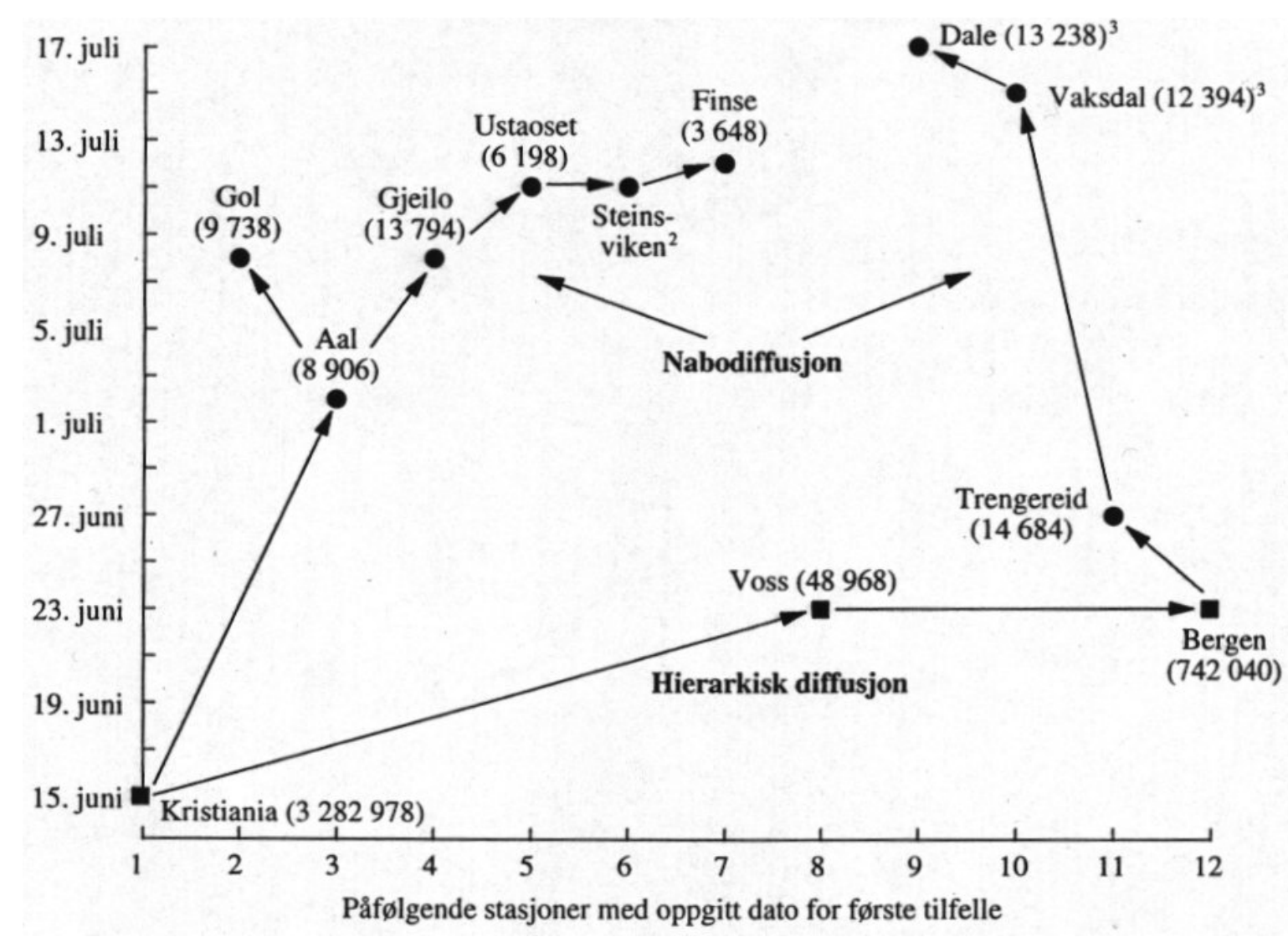

Figur 3. Spredning av influensa langs Bergensbanen under sommerepidemien ${ }^{1}$.

${ }^{1}$ Tall i parentes er antall ankomne passasjerer fra 1. juli 1918 - 30. juni 1919.

${ }^{2}$ Steinsviken vokterbolig ligger mellom Ustaoset og Haugastøl.

${ }^{3}$ Vaksdal fikk spanskesyken før Dale i "midten av juli". Plasseringen angir derfor ikke eksakt dato.

Kilder: Hansen (1923), medisinalberetningene for Bruvik, Voss og Aal 1918, Vaughan (1921), Hovedstyre for statsbanene (1920).

Andre jernbanestrekninger var trolig også viktige i spredningsprosessen i Sør-Norge. De første sykdomstilfellene på Kongsberg og Fredrikstad oppsto for eksempel etter at sykdommen ble importert med jernbanen, i begge tilfellene med bestemte personer fra Kristiania (Mb. for Kongsberg 1918, Varden 1983). Jernbanestrekningen mellom Trondheim og Løkken, Stavanger og Flekkefjord, Setesdalsbanen fra Kristiansand til Byglandsfjord, Aamlibanen fra Arendal til Tveitsund og Valdresbanen fra Eina til Fagernes, var sannsynligvis også viktige spredningskanaler (figur 1).

\section{Sosial interaksjon og lokal diffusjon}

Solberg (1919) mener at store deler av befolkningen i et lokalsamfunn kunne bli slått ut fordi ansatte på posthuset, telefonsentralen eller landhandleriet som regel fortsatte sitt arbeide selv om de var syke. Det er stor grunn til å tro at disse stedene var utgangspunktet for smittespredningen mange steder, og postfolk og postkunder var ofte blant de første som ble syke sommeren 1918 (Mb. for Alstadhaug, Gildeskaal, Kvæfjord, Leikanger, Namsos 1918). Feriereisende fra byene, såkalte landliggere, kan ha spilt en dobbel spredningsrolle mellom by og bygd i forbindelse med sommerferien. I begynnelsen av ferien kan de ha tatt med seg smitte fra byene til landsbygda, som til da ikke hadde fått sykdommen, og da ferien var slutt, og spanskesyken var i tilbakegang i byene, kan skolenes gjenåpning og hjemvendte ferieturister ha bidratt til at epidemien blusset opp igjen her i slutten av august og i begynnelsen av september $(\mathrm{Mb}$. for Balestrand, Bodø, Fana, Grong, Halsa, Hjelmeland, Kristiansand, Narvik, Nore og Opdal, Aalesund 1918, Varden 1983, Aarhus 1988). Soldater spilte trolig en tilsvarende dobbeltrolle mellom det sivile og militære samfunnet ettersom spanskesyken ofte ble innført i militærleirene med nye rekrutter, repetisjonssoldater og soldater som hadde vært på permisjon, mens dimitterte og permitterte soldater også tok sykdommen med seg hjem (Mb. for Fosnes, Hof, Sande, Skudenes, Syd-Varanger 1918, Skajaa 1921).

Fiskefeltene fungerte trolig som lokale spredningspunkter langs hele kysten under spanskesyken. Mange fiskere ble nemlig syke ute på fiskefeltene og tok med seg sykdommen hjem når de kom til land $(\mathrm{Mb}$. for Vikna, Kolvereid, Herøy, Aalesund 1918, Skajaa 
1921, DCM 1922, Hansen 1923). De tradisjonsrike høstmarkedene i begynnelsen av oktober fungerte trolig som utgangspunkt for intra-regional sykdomsspredning mange steder i landet. Eksplosiv utvikling av epidemien i store deler av Hedemarken amt skyldes sannsynligvis at folk brakte smitten med seg hjem etter besøk på Hamar og Tynset-mart'n (DCM 1922). Tilsvarende utvikling ble observert omkring bygdene på Otta etter et hestestevne på samme tid (Mb. Lesja 1918). For å hindre smittespredning til Kautokeino ble høstmarkedet i Alta avlyst. Avlysningen kom dessverre for sent og mange markedsfolk fra Kautokeino brakte smitten med seg hjem (Mb. for Alta 1918). Liknende begivenheter, for eksempel et idrettsstevne, bygdefester, mindre basarer, auksjoner eller et valgmøte, førte også til rask smittespredning under høstepidemien (Mb. for Kopervik, Overhalla, Lista, Sand, Stavanger, Skudenes 1918). Vi har også eksempler på lokale influensautbrudd etter større bryllup under de tre influensabølgene (Gulen og Askvoll, Singsaas, Overhalla 1918). Mange ble også ironisk nok smittet av spanskesyken etter deltakelse i begravelser (DCM 1922). I Selbu og Tydal var det en utbredt oppfatning at «spanskesyken fulgte treskeverket» (Brev fra Selbu og Tydal Historielag 1997). Det er ikke utenkelig at spanskesyken spredte seg når treskeverket ble flyttet mellom gårdene under kornhøsten, ettersom treskeprosessen krevde stor arbeidsinnsats og ofte foregikk i trekkfulle låver.

Den tredje influensabølgen oppsto i forbindelse med årsskiftet 1918/19, gjerne etter en julebasar eller en juletrefest, og det var gjerne de som hadde gått fri tidligere som nå ble syke $(\mathrm{Mb}$. for Dvergberg, Farsund, Fosnes, Halsa, Hvaler, Nedenes, Nesset, Skudenes 1918). Stor kontakt mellom familie og venner innendørs på denne tiden ga trolig gode muligheter for enkelttilfeller å utvikle og formere seg. For sjøbygdene spilte vårsild- og torskefiske den samme rollen (Mb. for Herøy, Gulen, Lebeseby, 1918, Skajaa 1921, Hansen 1923). I forbindelse med skolestart etter juleferien blusset også epidemien opp mange steder (DCM 1922).

\section{KONKLUSJON}

De første sporadiske tilfellene av spanskesyken i Norge oppsto i militærleire i begynnelsen av april 1918. Over tre måneder senere kom de første spredte tilfellene av det som skulle vise seg å være en ny stor influensapandemi. De første av disse oppsto i Kristiania, mest sannsynligvis etter smitteimport fra Skottland over Nordsjøen, og i Norges to nest største byer, Bergen og Trondheim, oppsto spanskesyken trolig etter smitteimport med passasjerer som kom fra hovedstaden med jernbanen. Sommerepidemien under spanskesyken begynte tidlig i de største byene langs kysten og i de mest trafikkerte og tettest befolkede industrisentra både langs kysten og i innlandet. Etter dette spredte sykdommen seg raskt fra sør til nord, fra kysten innover fjordene og fra de største byene og industrisentra via mindre byer og tettsteder til landsbygda langs de viktigste ferdselsveiene. Jernbanen og hurtigruten spilte trolig en viktig rolle i denne prosessen. I Nord-Norge var spredning langs kysten viktigst, men i Sør-Norge var både kyst- og innlandsspredning av sentral betydning. De første sykdomstilfellene av spanskesyken på bygdene ble i hovedsak observert blant feriereisende fra byene. Sykdom oppsto derfor tidlig på overnattingsplassene langs de viktigste kommunikasjonsveiene, ombord lugarer i dampskip og $\mathrm{i}$ kupéene på togene. Høstepidemien spredte seg relativt langsomt, trolig fra nord mot sør, og kunne like gjerne starte $\mathrm{i}$ byene som på bygdene. Vinterepidemien opptrådte spredt og sporadisk, tilsynelatende uten bestemt spredningsmønster og rekkefølge. Lokal sykdomsspredning under de ulike influensabølgene kan forklares med ulik sosial interaksjon.

Den mest slående epidemiologiske forskjellen mellom sommerepidemien og høstepidemien er kanskje spredningshastigheten. På sommeren spredte spanskesyken seg raskt og gjerne etter et hierarkisk mønster, mens høsten ble dominert av langsommere nabodiffusjon. Tilsvarende spredningsforløp ble også observert andre steder i verden under spanskesyken, blant annet $\mathrm{i}$ Japan og på Island (Sugiura 1977, Cliff et al. 1986). I Norge er spredning fra ytterst til innerst i Hardangerfjorden, Sognefjorden og Nordfjord, og spredning på Karmøy fra Haugesund i nord til Skudeneshavn i sør, gode eksempler på den store forskjellen i spredningshastighet. Mens sommerepidemien bare brukte to til tre uker på å spre seg fra ytterst til innerst i de tre nevnte fjordene, gikk det to til tre måneder før høstepidemien spredte seg tilsvarende strekning. Sommerepidemien på Karmøy brukte kun én uke på å spre seg fra Haugesund til Skudeneshavn, mens høstepidemien brukte åtte ganger så lang tid på den samme distansen (Skajaa 1921). Med dagens raske kommunikasjonsmidler og utbredt reisevirksomhet kan spredning over samme avstander skje tilsvarende raskere.

De store forskjellene i spredningshastighet og spredningsmønster under de tre influensabølgene kan sannsynligvis forklares ved at gjennomgått sykdomsforløp ga relativ immunitet mot senere utbrudd. Etter hvert som pandemien skred frem sto det derfor færre mottakelige individer til disposisjon for influensaviruset, og som et resultat av regionale forskjeller i opparbeidet immunitet, endret spanskesyken spredningsretninger, avtok i spredningshastighet og ebbet etter hvert ut. Jernbanen i innlandet og dampbåttrafikken langs kysten spilte sannsynligvis en viktig rolle $\mathrm{i}$ smittespredningen i Norge. Andre transportmidler og kommunikasjonsveier hadde sannsynligvis også stor betydning. I Sør-Norge gikk det for eksempel viktige automobilruter landeveien mellom Dombås og Åndalsnes, som en fortsettelse av Dombåsbanen, fra Fagernes via Bygdin til Lærdal, som en fortsettelse av Valdres- 
banen, og fra Gol gjennom Hemsedal til Maristova på Fillefjell (Mb. for Gol, Lesja 1918, Gram 1918). Dampskiprutene på innlandsfjordene er et annet eksempel. Ved endestasjonene til Aamlibanen og Setesdalsbanen har trolig dampskipene bistått videre sykdomsspredning oppover Nisserfjorden og Byglandsfjorden (Mb. for Aamli, Bygland, Valle 1918). Lokal sykdomsspredning kan også ha skjedd med hest eller til fots langs landeveien. Flere utenlandske studier har vist at kommunikasjonsnettverk, spesielt jernbanen, har vært viktig for innenlands spredning, mens båttrafikken har vært viktig langs kysten (Ohadike 1991, Patterson og Pyle 1983, 1991).

En av datidens leger uttalte at «set i sin helhet maa den nuværende influenza-epidemi betegnes som en av de største ulykker der har rammet vort samfund» (Harbitz 1919:88). Til tross for dette har spanskesyken fått overraskende liten oppmerksomhet når norsk historie generelt og historisk samfunnsmedisin spesielt, er blitt skrevet. Hva kan årsaken til dette være? Crosby (1989) hevder at «glemselen» kan skyldes at få sentrale maktpersoner døde. De fleste som døde av spanskesyken var under 40 år og maktpersonene var nok i mindretall blant disse. En annen årsak kan være at spanskesyken rammet i sluttfasen av første verdenskrig. De siste nyhetene fra krigen, fredsforhandlingene og stortingsvalget høsten 1918 dominerte den offentlige debatten og stjal følgelig hovedoppslagene i avisene. En tredje forklaring kan være at folk var vant med høy sykelighet og dødelighet, også blant unge mennesker. Tuberkulosen rammet for eksempel fortsatt hardt på denne tiden, spesielt menn i 20-årene. At mange unge mennesker bukket under for spanskesyken, gjorde derfor kanskje mindre inntrykk på folk enn man skulle tro i dag.

Denne artikkelen er den første omfattende spredningsstudien av en historisk influensapandemi i Norge. Integrering av matematiske spredningsmodeller og empiriske studier av sykdomsdiffusjon kan være en spennende tilnærming i fremtidige analyser (Cliff et al. 1981, 1986). Andre sentrale problemstillinger som bør vies oppmerksomhet i senere studier er nasjonal og regional sykelighet og dødelighet, samt sosioøkonomiske og demografiske konsekvenser av spanskesyken, herunder fertilitet, nuptialitet og befolkningsstruktur.

Artikkelen er basert på hovedfagsoppgave skrevet av artikkelforfatteren (Mamelund 1998). Jeg vil takke Erik Nymoen (SSB) og Jørgen Carling for nyttige kommentarer til en tidlig versjon av denne artikkelen. Liv Hansen (SSB) og Bjarne Øymyr (NSD) skal ha takk for å ha laget figurene. Jeg vil også takke Statistisk sentralbyrå (SSB) som har bidratt med gode arbeidsbetingelser under skriving av denne artikkelen.

\section{REFERANSER}

Aftenposten 28. mai 1918.

Aschehoug og Gyldendals store ettbindsleksikon. Oslo: Kunnskapsforlaget, 1997.

Brev fra Lesja Historielag v/Odd Reidar Hole 19/2-1998.

Brev fra Selbu og Tydal Historielag v/Gjertrud Evjen 2/6-1997.

Brochman SW (1936). Bidrag til epidemienes historie i Norge i eldre tider. Tidsskr Nor Lageforen 56 (7-10): 380-92, 401-46, 489-503 og 566-8.

Caplex (1997) (Cappelens ettbindsleksikon). Oslo: Cappelen.

Cliff AD, et al. (1991). Spatial Diffusion. An Historical Geography of Epidemics in an Island Community. Cambridge: Cambridge University Press.

Cliff AD, et al. (1986) Spatial Aspects of Influenza Epidemics. London: Pion.

Crosby A (1989). America's Forgotten Pandemic. The Influenza of 1918. Cambridge: Cambridge University Press.

DCM (1922). Sundhetstilstanden og medisinalforholdene 1918, NOS VII. 58. Kristiania.

DCM (1923). Sundhetstilstanden og medisinalforholdene 1919, NOS VII. 108. Kristiania.

Fuglum P (1988). Norge i støpeskjeen 1884-1919. Bind 12 i Knut Mykland (red): Norges historie. Oslo: Cappelen.

Gould P (1969). Spatial Diffusion. Washington: Association of American Geographers Resource Paper No. 4.

Gram J (red.) (1918). Rutebok for Norge 6te juli 1918 (Norges Communcationer). 1(1). Hovedstyret for Statsbanerne.

Great Britain Ministry of Health (1920). Report on the 1918-19 Pandemic of Influenza. Reports on Public Health and Medical Subjects, No. 4. London.

Hansen O (1923). Undersøkelser over influenzaens optrceden specielt i Bergen 1918-1922. Bergen: Arbeider fra Den medicinske Avdeling av Haukeland sykehus. Skrifter utgit ved Klaus Hanssens Fond, Nr. III. 
Hansson RS (1919). Litt om influenza («den spanske syke», la grippe, «catarrhus epidemicus») før og nu. Tidsskr Nor Laegeforen 39 (7): 268-72, (9): 345-8.

Harbitz F (1919). Litt om influenza. Forsikringstidende, Norsk Tidsskrift for Forsikringsvoesen 23 (5-6): 71, 87-8.

Harboe, A. (1976): Spanskesyken 1918-1919 og svineinfluensavirus. Tidsskr Nor Lageforen 96 (16): 914.

Hoel A (1966, 1967). Svalbard. Svalbards historie 1596-1965, Bind II (1966) og Bind III (1967). Sverre Kildahls boktrykkeri.

Horton R (1996). The infected metropolis. Lancet 347: 134-5.

Hovedstyre for statsbanene (1920). Norges Jernbaner. Beretning fra året 1. juli 1918 - 30. juni 1919. NOS. VI. 172. Kristiania.

Hoyle L (1968). The Influenza Viruses. New York: Springer.

Keyser GW (1918). «Den spanske syke» - Pseudo-influenza. Tidsskr Nor Lageforen 38 (18): 801-5.

Kilbourne ED (red.) (1975). The Influenza Viruses and Influenza. New York: Academic Press.

Kristiania sundhetskommision (1919). Beretning fra Kristiania sundhetskommision og Kristiania kommunale sykehus for året 1918. Kristiania.

Krogstad BR (1987). Samhold og strid. Bygdebok for Meråker 1874-1987, Bind II. Meråker kommune.

Lorentzen L, Sørdahl RW (red.) (1988). Arhundrets krønike. Oslo: Gyldendal.

Mamelund S-E (1998). Estimating the death toll of Spanish Influenza: the case of Norway. Presentert på konferansen «Reflections on the Spanish Flu Pandemic after 80 years - Causes and Consequences», Cape Town, SørAfrika, 12.-15. September 1998.

Mamelund S-E (1998). Spanskesyken i Norge 1918-20: Diffusjon og Demografiske Konsekvenser. Hovedoppgave i samfunnsgeografi. Oslo: Institutt for sosiologi og samfunnsgeografi, Universitetet i Oslo, høsten 1998.

Mamelund S-E, Borgan JK (1996). Kohort- og periodedødeligheten i Norge 1846-1994 (Cohort and period mortality in Norway 1846-1994). Oslo-Kongsvinger: Statistisk sentralbyrå, Rapporter 96/9.

Meade M, et al. (1988). Medical Geography. London: Guilford Press.

Medisinalberetningene (utrykte) for refererte legedistrikter 1918 og 1919. Pakkenummer 659-908, hyllenummer 2C17813-2C17842, Riksarkivet i Oslo.

Melby F (1955). Influenzaens epidemiologi og problemet om spanskesyken 1918-19. Kosthold og Helse 1 (1): 177-80.

Minneoppgave nr. 2 for Finnmark 1981. Institutt for Kulturstudier, Samlingsseksjonen, Universitetet i Oslo.

Morill RL, Dormitzer JM (1979). The Spatial Order. An Introduction to Modern Geography. North Scituate, Massachusetts: Doxbury Press.

Nordlander O (1932). Influensaen och des framträdande särskilt inom svenska armen under epidemierna 1918/19 samt 1920. Tidskrift i Militär Halsovård 57 (2): 63-187.

Ohadike DC (1991). Diffusion and physiological response to the influenza pandemic of 1918-1919 in Nigeria. Soc Sci Med 32 (12): 1393-9.

Patterson KD (1985). Pandemic and epidemic influenza, 1830-1848. Soc Sci Med 21 (5): 571-80.

Patterson KD, Pyle GF (1983). The diffusion of influenza in Sub-Saharan Africa during the 1918-1919 pandemic. Soc Sci Med 17 (17): 1299-1307.

Patterson KD, Pyle GF (1991). The geography and mortality of the 1918 influenza pandemic. Bull Hist Med $\mathbf{6 5}$ (1): 4-21.

Pyle GF, Patterson KD (1987). The geography of influenza. Am Geogr Soc Focus 37 (3): 6-23.

Ramberg R (1969). Spanskesyken i Norge 1918-1919. Tidsskr Nor Loegeforen 89 (22): 1709-12.

Rice G (1989). Microgeography of historical influenza mortality: A New Zealand example from the 1918 pandemic. Proceedings of the 1989 NZ Demographic Society Conference.

Schønfelder TH (1919). Influenza. Tidsskr Nor Laegeforen 8 (39): 309-11.

Shannon GW, Pyle GF (1989). The origin and diffusion of AIDS: a view from medical geography. Ann Assoc Am Geogr 79: 1-24.

Skajaa K (1921). Om influenza og influenzapneumoni. En patologisk-anatomisk og bakteriologisk undersøkelse. Fra dr. med. F.G. Gades patologiske institutt. Skrifter utgit ved Klaus Hanssens fond, Nr. II. Bergen.

Solberg M (1919). Forholdsregler og midler mot influenza. Tidsskr Nor Lageforen 39 (7): 273-4.

Speilberg TT (1919). «Den spanske syke». Norsk Tidsskrift for Militormedicin 22: 179.

Sugiura Y (1977). Spatial diffusion of Spanish influenza in Japan, 1916-26. Geogr Rev Japan 50 (4): 201-15.

Sørensen J (1998). Panserskipene 1895-1940. I unionskamp og på vakt for nøytraliteten. Forsvarsmuseets småskrifter nr. 19. 
Teigum I (1975). «Det året Spanska for». I: Lindsheim P, Bruheim JM (red.): Arrbok for Gudbrandsdalen 1975, 43: 141-8. Dølaringen og Gudbrandsdal historielag, Dølaringen Boklag.

Thuesen N-P (1997). Norges historie i årstall. Orion forlag.

Ustvedt Y (1919). Iagttagelser under influenzaepidemien i juli 1918. Norsk Magazin for Lagevidenskaben 80 (1): $1-20$.

Vahtola J (1994). Espanjantauti Suomessa 1918-1920. I: Kulttuuri, politiikka, historia, koulutus ja lehdistö. Oulu. Varden (1983). Spanskesyken 1918. Arstidsskrift for Onsøy Historielag, 1-15.

Vaughan WT (1921). Influenza. An Epidemiological Study. The American Journal of Hygiene Monograph Series, No. 1. Baltimore.

Wilton P (1993). Spanish flu outdid WW1 in number of lives claimed. Can Med Assoc J 148 (11): 2036-7.

Åman M (1990). Spanska Sjukan. Den svenska epidemin 1918-1920 och dess internationella bakgrund. Historiska Institutionen, Uppsala Universitet. Stocholm: Almqvist \& Wiksell International.

Aarhus I (1988). I spanskesykens tegn. Ein rapport om epedemien i åra 1918-1919. Tidsskrift for Sunnmøre Historielag 64: 57-118. 